\title{
Identification of a historic horse ecotype analyzing speech content in central Brazil
}

[Resgate de um ecótipo equino histórico mediante análise de conteúdo de discurso no Brasil central]

$$
\begin{aligned}
& \text { D.C. Silva }{ }^{1} \text {, M.C. Silva }{ }^{2} \text {, F.F. Goulart }{ }^{3} \text {, A.S. da Cruz }{ }^{4} \text {, M.I. Moura } \\
& \text { M.C.S. Fioravanti } \\
& \text {, J.R.B. Sereno }
\end{aligned}
$$

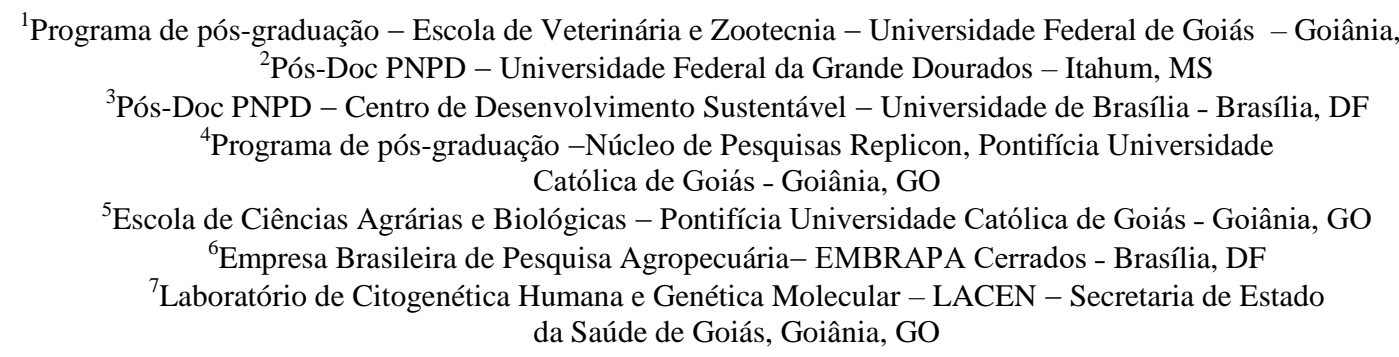

$\mathrm{GO}$

D.C. Silva

https://orcid.org/0000-0002-4984-9019 M.C. Silva https://orcid.org/0000-0002-7599-1967 F.F. Goulart https://orcid.org/0000-0002-6327-528 https://orcid.org/0000-0002-4736-945X M.I. Moura https://orcid.org/0000-0002-2588-6923 M.C.S. Fioravanti https://orcid.org/0000-0002-4993-5523 R.B. Sereno https://orcid.org/0000-0001-9773-055X https://orcid.org/0000-0003-0753-3814

\begin{abstract}
This study represents a first attempt to rescue germplasm of a traditional domestic equine cited in early Iberian and South American literature as Curraleiro horse. As an effort to identify and possibly characterize this type of horse we accessed traditional knowledge in strategic rural areas. Most areas were configured by hinterland settlements founded by runaway slave communities from the sixteenth century. Twenty interviews were conducted and analyzed using classical Speech Content Analysis. As a result, five response categories were recognized: 1) Identification and location of Curraleiro horses; 2) Characterization of Curraleiro horses; 3) Historical aspects; 4) Curraleiro horse conservation prospects and 5) Sanitary and productive aspects of Curraleiro horse breeding. We concluded that although scarce, the Curraleiro horse, cited in literature, still exists and showed phenotypical features which allow fine discrimination from any officially recognized breed in Brazil. Our findings may open the door for the recognition of a genuine animal resource which could play a role in rural development for specific regions and traditional communities. Speech Content Analysis was effective for in loco identification and characterization of rare traditional livestock. Thus, we encourage the usage of this tool as an alternative to subsidize identification and genetic conservation programs worldwide.
\end{abstract}

Keywords: horse, equine, local breed, animal genetic resource

\section{RESUMO}

Esse estudo representa uma primeira tentativa de resgate de germoplasma em um equino doméstico tradicional citado em literatura precoce Iberiana e Sul Americana como um cavalo Curraleiro. Num esforço de identificar e possivelmente caracterizar esse tipo de cavalo, acessamos conhecimento tradicional em diversas áreas rurais estratégicas. A maioria consistia em assentamentos rurais fundados por comunidades escravas foragidas no século dezesseis. Vinte entrevistas foram conduzidas e analisadas utilizando análise de conteúdo de discurso clássico. Como resultado, cinco categorias de resposta foram reconhecidas: 1) Identificação e localização de cavalos Curraleiros; 2) Caracterização de cavalos curraleiros; 3) Aspectos históricos, 4) Perspectivas de conservação, e 5) Aspectos sanitários e produtivos da criação de cavalos Curraleiros. Concluímos que, apesar de escasso, o cavalo Curraleiro, citado na literatura, ainda existe e apresenta características fenotípicas que permitem discriminação de raças oficialmente reconhecidas no Brasil. Nossos achados podem abrir alas para o reconhecimento de um recurso animal genuíno que pode ter um papel no desenvolvimento rural em regiões específicas e comunidades tradicionais. Análise de conteúdo de discurso foi eficaz para identificação e caracterização in loco de criação tradicional rara. Desta forma, encorajamos o uso dessa ferramenta como alternativa para subsídio de identificação e programas de conservação genética ao redor do mundo.

Palavras-chave: cavalo, equino, raça local, recurso genético animal

Recebido em 25 de agosto de 2017

Aceito em 31 de outubro de 2018

*E-mail: dnl.conrado@gmail.com 


\section{INTRODUCTION}

During early colonization of the South American continent, domestic livestock from Europe slowly spread out through in a remarkable scenario of climate and cultural diversification. This phenomenon began in the sixteenth century, where several European livestock breeds were challenged to adapt and breed for the purpose of land use and food supply. Such scenario configures the context in which today several horse breeds roam the South American landscape (Egito et al., 2002).

Currently, Brazil has the biggest equine herd the Latin America and the third biggest herd in the world (Weiblen et al., 2015). About seven of eleven Brazilian horse breeds were formed mainly by natural selection, thus, formed geographically isolated groups. Until the 1970's, the naturally selected breeds Pantaneiro, Campeiro, Nordestino, Marajoara, Puruca, Lavradeiro, and Baixadeiro belonged to a unique group called Comum. The Comum equine group also included horses from the State of Goiás, central Brazil, where they were known as Curraleiro horses (Goulart, 1964). In the early years of the $20^{\text {th }}$ century, references to the Curraleiro horses described them as restrict population, small standard, enduring and agile breed adapted to the geographical and landscape challenges of Central Brazil. Overall, these horses were small built sturdy horses that satisfactorily met the working needs of local cattle breeders (Silva, 1908; Lloyd, 1913; Goulart, 1964).

Since the 1980's, there has been a consistent increase in the knowledge about both the constitution and the economical and social importance of Brazilian horse breeds. Consequently, project proposals have been aimed at the conservation of naturally selected horse breeds in Brazil. However, for some specific and isolated populations, such as Curraleiro horses, little or no conservation initiatives have been proposed. Comparing livestock species: horses (23\%), followed by rabbits (20\%), porcine $(18 \%)$, and bovine $(16 \%)$ are the domesticated mammals with higher proportions of breeds at risk of extinction with a negative impact on the production of agricultural commodities worldwide (The state..., 2007).
Although speech analysis, as other qualitative approaches, are not common in the animal sciences, it has a history of more than 60 years of use in communication, journalism, sociology, psychology, business, and other disciplines (Neuendorf, 2017). Nevertheless, some researches have inserted these methodologies in the context of animal science and as a diagnostic tool for genetic animal conservation (Gordo et al., 2013; Solano et al., 2013; Silva et al., 2013).

We attempt to identify and characterize a potential equine genetic resource forgotten most probably in the State of Goiás, home to a peculiar horse ecotype known as Curraleiro and regarded as highly adapted to the harsh conditions of the Brazilian savanna. This work also attempts to propose guidelines for all researchers who aim to rescue animal germplasm and genetic resources worldwide.

\section{MATERIAL AND METHODS}

Exploratory quick interviews were conducted with local members of the community from several pre chosen areas, including small scale horse breeders (potential Curraleiro horse keepers) or people that showed any knowledge or opinion regarding historic aspects of horse usage in the community. By identifying these people, in parallel, a semi-structured questionnaire containing open questions was applied in order to collect information regarding any possibility to characterize Curraleiro horses in any aspect.

Answers of interviews were organized according to stereotypes: i) Keeper (horse breeder with no knowledge regarding the background of the animals); ii) Knowledge holder (interviewee who presented historic data regarding Curraleiro horses); iii) Keeper/Knowledge holder (i + ii); iv) Trader (buys and sells horses and had data regarding horses trading in the region, regardless of horse breed); v) Resident (interviewee was not a breeder neither a trader, but knows Curraleiro horses for residing in the studied region). The sampling scheme was defined by a nonprobabilistic technique. At the end, data from interviews were registered from four counties in the State of Goiás: Cavalcante, Nova Roma, Iaciara and Silvânia.

Speech content was analyzed using the model proposed by Laurence Bardin (Bardin, 2004), 
defined as a combination of quantitative and qualitative methods which consists of three basic steps (pre-analysis, analysis and fragmentation and the inferential stage). In the first step, all answers were transcript into a single text to allow a first appraisal of the content and deletion of residual data. Answers were grouped up regardless of the order of interrogations in the questionnaire to originate a corpus. Subsequently, careful and systematic reading was performed (corpus impregnation). The second step allowed discrimination of smaller fragments of information which were separated using a slash symbol (/), creating elementary context units (ECU). Each ECU contained a minimum number of words with a specific meanings and an overall brief idea, i.e, "/I can affirm to you that it is a very enduring horse/ For us, the Curraleiro horse can keep working harder than the other horse breeds in our region/". Sentences with meanings of opposition, adversity, complementarity or deductive sentences were maintained intact into a same ECU. Sentences with confirmative or reiteration meanings were clipped into different ECUs. Subsequently, fragments were agglomerated into similar thematic groups, originating categories and primary subcategories. When possible, primary subcategories were divided into secondary and even tertiary subcategories. To observe the structure of categories and subcategories, the ECUs were quantified in absolute (f) and relative (\%) frequencies.

In the third and final phase of analysis categories and subcategories were sorted out and discussed by a research committee. Interpretations of results and inferences were based on engaged professional experience, theoretical frameworks and feedback from the field reports. This allowed the categories and subcategories to be named according to their content ("posteriori category nomination" or "baptism") which is the last step before obtaining a summary of results.

\section{RESULTS}

The study sample was comprised of 20 interviews: $45 \% \quad$ (9) keepers, $25 \% \quad$ (5) keepers/knowledge holders, $15 \%$ (3) residents, $10 \%$ (2) traders, and 5\% (1) knowledge holder. Figure 1 shows the distribution of respondents in each county.

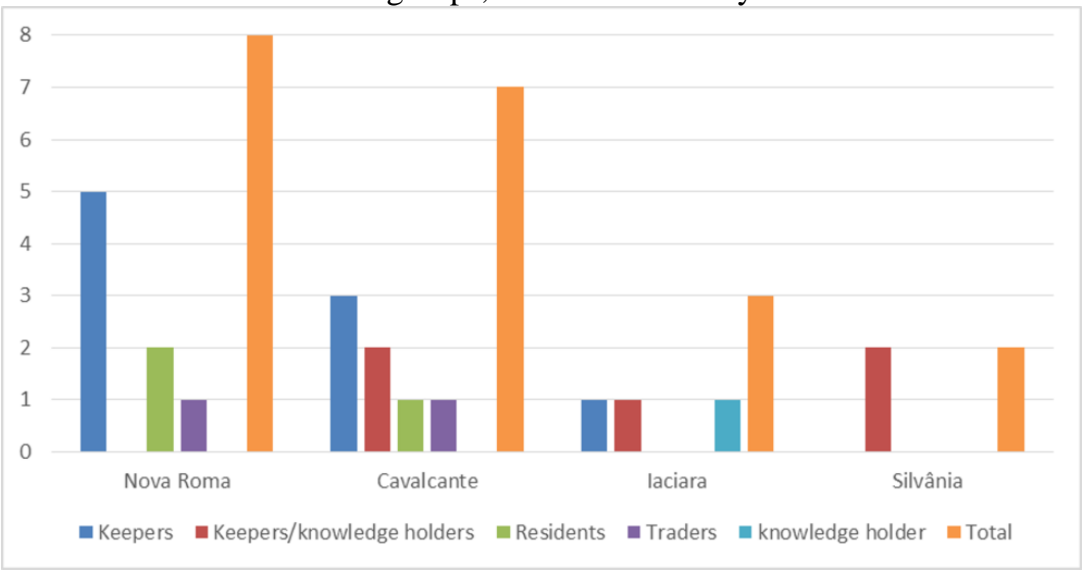

Figure 1. Profile and amount of respondents of the questionnaire in four counties in central Brazil.

By grouping the elementary context units (ECUs) during the analysis of the corpus, five categories emerged and were baptized according to their content: 1) Identification and location of Curraleiro horses, comprising $21.9 \%$ of the ECUs; 2) Characterization of Curraleiro horses, comprising $44.2 \%$ of ECUs; 3) Historical aspects, comprising $23.5 \%$ of ECUs; 4) Curraleiro horse conservation prospects, consisting of 5.8\% of ECUs; and 5) Sanitary and productive aspects of Curraleiro horse breeding, comprising $4.6 \%$ of ECUs. The sub categorization in each category and the respective frequency of the ECUs are shown in the following tables.

\section{DISCUSSION}

The respondents from Nova Roma county contributed with most of the interviews (8 out of $20)$. This county also had the largest number of Curraleiro horse keepers (5 out of 8 ). This could 
be explained by the precarious road access to Nova Roma, mostly unpaved dirt roads, which could hinder the introduction of modern horse in the region. Results indicate that the concentration of local horse keepers within that municipally is reinforced by the farmers' needs that increasingly demand a local more rustic breed. Similarly, the county of Cavalcante is comprised of areas of difficult access, including Kalunga's Historical and Cultural Heritage Site, a closed community of Brazilian Afro-descendants (Quilombola communities). Thus, social and geographical aspects restrict the provision of agricultural innovation trends in Cavalcante, which may reflect in the existence and greater demand for locally adapted livestock.

It was difficult to find people who had any knowledge about Curraleiro horses in the county of Iaciara. It occurred probably because the paved road networks may have facilitated the introduction of horse breeds of high commercial values which may have reduced the interest for breeding local horses. Therefore, local economy in this county has been focused on modern agribusiness, as well as the majority of municipalities in central Brazil, which may have facilitated abrupt substitution of livestock breeds. The State of Goiás has the fourth largest equine effective population size in Brazil (Produção..., 2013), comprised of breeds with added value, such as Quarter Horses. The same difficulties have been found in the county of Silvânia, but the presence of two keepers/knowledge holders is justified because they belonged to a family of local breeds admirers, including with previous records of keeping local breeds, as the Crioulo horse and the Curraleiro Pé-Duro cattle.

It is important to highlight that throughout the data collection we perceive repeatability of the speeches between different interviewees that characterized and mischaracterized the Curraleiro horse. We traveled to different counties and the interviewees gave us the same or similar information.

The following is a discussion of the results of the speech elements by categories:

Category 1 - Identification and location of Curraleiro horses (Table 1).

Table 1. Absolute and relative frequencies of the subcategories corresponding to Category $1-$ Identification and location of Curraleiro horses - in a study regarding the speech content analysis in central Brazil

\begin{tabular}{|c|c|c|c|c|c|c|}
\hline \multicolumn{7}{|c|}{ Category 1: Identification and location of Curraleiro horses } \\
\hline $\begin{array}{c}\text { Primary } \\
\text { Subcategory }\end{array}$ & $\begin{array}{l}\text { Secondary } \\
\text { Subcategory }\end{array}$ & $\begin{array}{c}\text { Tertiary } \\
\text { Subcategory }\end{array}$ & $\mathrm{f}$ & $\begin{array}{l}\text { PS } \\
(\%)\end{array}$ & $\begin{array}{l}\mathrm{C} 1 \\
(\%)\end{array}$ & $\begin{array}{l}\text { TCat } \\
(\%)\end{array}$ \\
\hline \multirow{8}{*}{$\begin{array}{l}\text { Perceptions about the } \\
\text { existence of an equine } \\
\text { group }\end{array}$} & \multirow{4}{*}{ Denominations } & Curraleiro & 22 & 27.8 & 20.2 & \multirow{12}{*}{21.9} \\
\hline & & Comum & 14 & 17.7 & 12.8 & \\
\hline & & Pé-duro & 8 & 10.1 & 7.3 & \\
\hline & & Piquira & 1 & 1.3 & 0.9 & \\
\hline & \multirow{4}{*}{ Breed Contextualization } & $\begin{array}{l}\text { Constitution of a distinct } \\
\text { horse group }\end{array}$ & 14 & 17.7 & 12.8 & \\
\hline & & They are not ponies & 6 & 7.6 & 5.5 & \\
\hline & & $\begin{array}{l}\text { The Curraleiro is to linked } \\
\text { Pantaneiro horses }\end{array}$ & 5 & 6.3 & 4.6 & \\
\hline & & $\begin{array}{l}\text { Not belong to an official } \\
\text { breed }\end{array}$ & 9 & 11.4 & 8.3 & \\
\hline \multirow{4}{*}{$\begin{array}{l}\text { Current presence of } \\
\text { Curraleiro horses in } \\
\text { communities }\end{array}$} & \multicolumn{2}{|c|}{ Current difficulty finding specimens } & 16 & 53.3 & 14.7 & \\
\hline & \multirow[t]{3}{*}{ Most likely places to find } & $\begin{array}{l}\text { County of Paranã and } \\
\text { Arraias }\end{array}$ & 5 & 16.7 & 4.6 & \\
\hline & & Araí village & 7 & 23.3 & 6.4 & \\
\hline & & $\begin{array}{l}\text { County of Nova Roma } \\
\text { and Iaciara }\end{array}$ & 2 & 6.7 & 1.8 & \\
\hline Total & & & 109 & - & 100 & \\
\hline
\end{tabular}

f - Absolute frequency of ECUs; PS - Relative frequency to the primary subcategory; C1 - Relative frequency to category 1; TCat - Relative frequency to the total ECUs including all five categories. 
Based on ECU, Curraleiro (27.8\%) was the most frequent denomination in the primary subcategory with respect to the perception of the interviewees about the occurrence of an isolated local equine group in Goiás. This is the term used to describe this horse in reports of Silva (1908), Lloyd (1913) and Goulart (1964). Although different denominations occurred, such as Comum, Pé-duro, and Piquira, Curraleiro was the term considered to be impregnated in the speeches. The denomination Comum lingered among the interviewees, corresponding to $17.7 \%$ of the primary subcategory regarding the perception about the horses. This is possibly due to the habitual random crosses of horses that led to a group of mongrel horses with parents of different breeds (Hermsdorff, 1956; Goulart, 1964; Torres and Jardim, 1979). Therefore, we defend that the denomination Curraleiro is representative and should be the term adopted to describe this particular group of horses. At the present, any discussion regarding the recognition of the breed seems to be precipitated. However, the identification of stallions and mares seems urgent if conservation of this kind of horse is under consideration.

With respect to breed contextualization, within the primary subcategory Perception about the horses, the Curraleiro was identified as a distinct group of horses, distinct from ponies and other officially recognized breeds. Some ECU also linked the Curraleiro to the Pantaneiro horse breed. Pantaneiro's historical formation included some degree of admixture, including genetic introgression with horses from Goiás (Goulart, 1964).

In the primary subcategory, Current presence of Curraleiro horses in the communities, the majority of ECUs $(53.3 \%)$ were related to the current struggle finding characteristic specimens of Curraleiro horses in the region. In the current study, the most likely habitat for Curraleiro horses is the village of Araí in the county of Cavalcante. This finding corroborates with Silva (1908) who reported Vão do Paranã as the most likely area to find Curraleiro horses in Brazil. Category 2 - Characterization of Curraleiro horses (Table 2).

Within the morphological characterization in category 2 , the description of the overall body size of horses stood out, which ranged from small to medium sizes $(50.0 \%)$. This is in agreement with Goulart (1964) who described Curraleiro horses being small, with a maximum size which would reach the average height of horses in Brazil at that time. In another study about Brazilian horse breeds, the authors argued that the small size of Nordestino horses could be due to inbreeding of animals, extensive and poor husbandry conditions, subjecting Nordestino horses to food and nutritional deficits (Melo et al., 2011). Similarly, this could be the case for Curraleiro horses. In the current study, respondents highlighted that the small body size of Curraleiros was assumed to be suitable because of the characteristic of the vegetation and landscape.

With respect to the hooves of Curraleiro horses, the interviewees described them as small and naturally inclined, namely "donkey hooves", a description that appeared in $10.9 \%$ of ECUs under the morphology subcategory. This observation was also reported by Melo et al. (2011) while describing the hooves of Nordestino horses. On the other hand, Marks (2000) reported hoof slopes $\geq 61^{\circ}$ as an abnormal condition, called clubfoot, which could result in osteoarticular disorders of hooves in horses. In the current study, the respondents described the hooves of Curraleiro horses to have a high slope. Despite this observation, interviewees related no pathological conditions or orthopedic disorders in the hooves of Curraleiro horses. The morphology of the hooves in Curraleiro horses was described as an adaptation to their habitat, thus, it had not been perceived as an abnormal condition.

Another important morphologic trait of Curraleiro horses, cited in $10.9 \%$ of the primary subcategory, was their peculiar hip anatomy. Interviewees characterized the hip of Curraleiro horses to be short and steep, describing it as a "pig hip". Although at lower frequency, other distinct phenotypic features of Curraleiro horses were also cited by the respondents, including thin mane and tail, several coat colors, presence of hair in pastern and fetlock regions, and small head. Apparently, the phenotypic traits cited in a lower frequency were less important to characterize Curraleiro horses. 
Table 2. Absolute and relative frequencies of the subcategories corresponding to Category 2 Characterization of Curraleiro horses - in a study regarding the speech content analysis in central Brazil

\begin{tabular}{|c|c|c|c|c|c|c|}
\hline \multicolumn{7}{|c|}{ Category 2: Characterization of Curraleiro horses } \\
\hline Primary Subcategory & Secondary Subcategory & Tertiary Subcategory & $\mathrm{f}$ & PS (\%) & $\begin{array}{l}\mathrm{C} 2 \\
(\%)\end{array}$ & $\begin{array}{l}\text { TCat } \\
(\%)\end{array}$ \\
\hline \multirow[t]{8}{*}{ Morphology } & \multicolumn{2}{|c|}{ Small to medium body size and height } & 46 & 50.0 & 20.9 & \multirow{24}{*}{44.2} \\
\hline & \multicolumn{2}{|c|}{ Small and inclined hooves ("donkey hooves") } & 10 & 10.9 & 4.5 & \\
\hline & \multicolumn{2}{|c|}{ Short and steep hip ("Pig hip") } & 10 & 10.9 & 4.5 & \\
\hline & \multicolumn{2}{|l|}{ Small ears } & 8 & 8.7 & 3.6 & \\
\hline & \multirow[b]{2}{*}{ Coat color traits } & Several colors & 9 & 9.8 & 4.1 & \\
\hline & & Thin mane and thin tail & 3 & 3.2 & 1.4 & \\
\hline & \multicolumn{2}{|c|}{ Hair in pastern and fetlock regions } & 4 & 4.3 & 1.8 & \\
\hline & \multicolumn{2}{|l|}{ Small head } & 2 & 2.2 & 0.9 & \\
\hline \multirow[t]{7}{*}{ Functionality } & \multicolumn{2}{|c|}{ High Endurance } & 24 & 29.6 & 10.9 & \\
\hline & Adaptation to rocky ground & nountains & 14 & 17.3 & 6.4 & \\
\hline & \multicolumn{2}{|c|}{ Good for working and to manage cattle } & 13 & 16.0 & 5.9 & \\
\hline & \multicolumn{2}{|c|}{ Agility and skill } & 15 & 18.5 & 6.8 & \\
\hline & \multicolumn{2}{|l|}{ Good horses in general } & 4 & 4.9 & 1.8 & \\
\hline & \multirow[t]{2}{*}{ Gait } & Ambler & 5 & 6.2 & 2.3 & \\
\hline & & Trotter & 6 & 7.4 & 2.7 & \\
\hline \multirow[t]{2}{*}{ Temperament } & \multicolumn{2}{|l|}{ Warmblood } & 10 & 83.3 & 4.5 & \\
\hline & \multicolumn{2}{|l|}{ Coldblood } & 2 & 16.7 & 0.9 & \\
\hline \multirow{7}{*}{$\begin{array}{l}\text { Characteristics of } \\
\text { exclusion }\end{array}$} & \multicolumn{2}{|c|}{ Larger hooves and not adapted to the rocky regions } & 9 & 25.7 & 4.1 & \\
\hline & \multicolumn{2}{|c|}{ Low endurance } & 9 & 25.7 & 4.1 & \\
\hline & \multicolumn{2}{|l|}{ Brawny neck } & 3 & 8.6 & 1.4 & \\
\hline & \multicolumn{2}{|l|}{ Large hip } & 3 & 8.6 & 1.4 & \\
\hline & \multirow{2}{*}{\multicolumn{2}{|c|}{$\begin{array}{l}\text { Large body size } \\
\text { Uncomfortable gait }\end{array}$}} & 4 & 11.4 & 1.8 & \\
\hline & & & 3 & 8.6 & 1.4 & \\
\hline & \multicolumn{2}{|l|}{ Wide animal } & 4 & 11.4 & 1.8 & \\
\hline Total & & & 220 & - & 100 & \\
\hline
\end{tabular}

f - Absolute frequency of ECUs; PS - Relative frequency to the primary subcategory; C2 - Relative frequency to category 2; TCat - Relative frequency to the total of ECUs including all five categories.

Within the primary subcategory of functionality, endurance was the attribute mostly reported $(29.6 \%)$ in all ECUs, which was in agreement with Lloyd (1913) and Goulart (1964). In Curraleiro horses, respondents attributed horse endurance to the long daily hours of work that this horse tolerates with little susceptibility to common diseases. Most Brazilian horse breeds have emerged from natural evolution of their ancestors and are often object of research because of their evident endurance and rusticity traits. In this scenario, Pantaneiro, Crioulo, Campeiro, Nordestino, Baixadeiro, Lavradeiro, Marajoara, and Puruca are breeds known to be study (Braga, 2000; Marques et al., 2001; Santos et al., 2003; Melo et al., 2011; Silva et al., 2012; Amaral et al., 2013; Solano et al., 2013). Additionally, vast rocky grounds in the region were Curraleiro horses were cited in literature, and identified in the present study, may have been the most important driver for adaptation regarding the hooves, indicated by $17.3 \%$ of ECUs. Curraleiro horse keepers reported that only horses with small and strong hooves would thrive in such terrain. Adapted and resistant hooves were also highlighted for Nordestino, Lavradeiro, and Pantaneiro Brazilian horse breeds (Santos et al., 2003; Mcmanus et al., 2010b; Melo et al., 2011).

In $18.5 \%$ of ECUs related to functionally, Curraleiros were defined as agile and skillful animals. These traits are related to their cognitive abilities and are mostly associated with their ability to work with reins. The respondents also mentioned other abilities, including the Curraleiro's suitability to manage herds of cattle (16.0\% of ECUs) and to yield rapidly upon 
command, which is adequate to efficiently work with large herds in large fields. Gait was not found as a relevant attribute in Curraleiro horses.

In the primary subcategory of temperament, most ECUs characterized Curraleiro horses as warmblood animals (83.3\%). However, the primary subcategories of Temperament and Characteristics of exclusion did not include relevant ECUs for the characterization of Curraleiro horses. Figure 2 shows common features for Curraleiros.
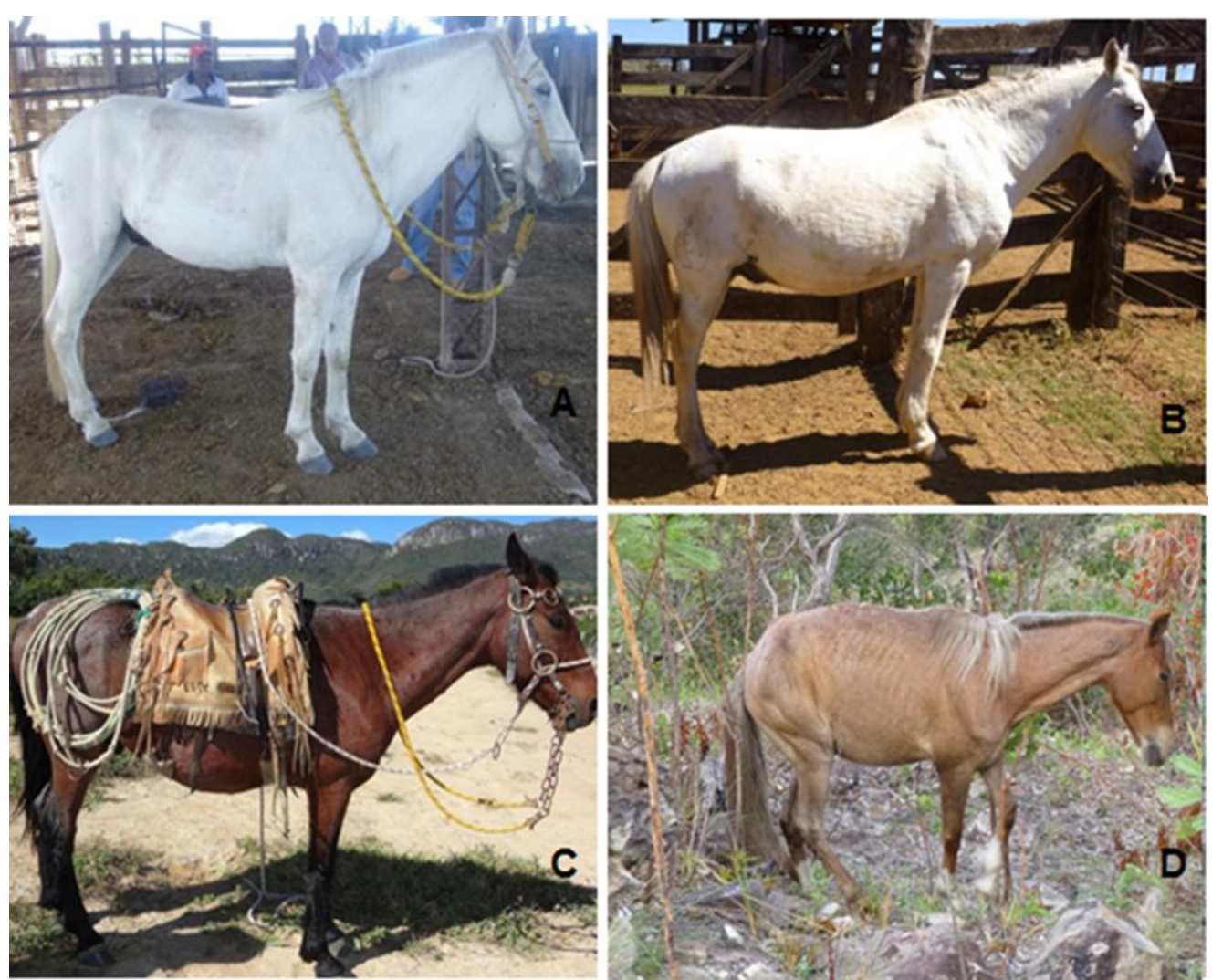

Figure 2. Horse specimens observed throughout the study in the Brazilian savannas. Common features for Curraleiro horses, as suggested by interviewees, are noticed in the animals A to C. A and B: Horses with similar morphology, showing small to medium body size and height, including "donkey hoof" and "pig hip"; C: Horse with small body and height, and hooves ideal for work according to its breeders; D: A mongrel horse, in spite of the specimen features did not match the expected ones for Curraleiro horses, in the figure it is possible to observe the stony ground of the region in which the Curraleiro horses are adapted and live in the Brazilian savannas. Category 3 - Historical aspects (Table 3).

After analyzing the ECUs of the primary category Presence and importance of Curraleiro in the past, it was evident that large quantities of Curraleiro horses existed in the savannas (40\%). The animals were mostly used for cattle management and for transportation of people and goods. Although less frequent, Curralerio horse were also used for leisure.

Only few ECUs were included in the context of the dynamic formation and commercialization of
Curraleiro horses. There were two reports referring to the animals that originated in the State of Goiás and another two indicating their origin in the southeast of Brazil, which is the same Brazilian region of origin for Mangalarga, Mangalarga Marchador, and Campolina breeds. Three citations in the ECUs indicated that Curraleiro horses were destined for the State of Mato Grosso in western Brazil, the same region where the Brazilian Pantaneiro horse breed evolved. 
Table 3. Absolute and relative frequencies of the subcategories corresponding to Category 3 - Historical aspects - in a study regarding the speech content analysis in central Brazil

\begin{tabular}{|c|c|c|c|c|c|c|}
\hline \multicolumn{7}{|c|}{ Category 3: Historical aspects } \\
\hline Primary Subcategory & Secondary Subcategory & Tertiary Subcategory & $f$ & $\begin{array}{l}\text { PS } \\
(\%)\end{array}$ & $\begin{array}{l}\mathrm{C} 3 \\
(\%)\end{array}$ & $\begin{array}{l}\text { TCat } \\
(\%)\end{array}$ \\
\hline \multirow{5}{*}{$\begin{array}{l}\text { Presence and importance } \\
\text { of the Curraleiro in the } \\
\text { past }\end{array}$} & \multicolumn{2}{|c|}{ Large troop of Curraleiro horses } & 12 & 40.0 & 10.3 & \multirow{13}{*}{23.5} \\
\hline & \multirow{4}{*}{ Use } & $\begin{array}{l}\text { Transport and management } \\
\text { of cattle herds }\end{array}$ & 7 & 23.3 & 6.0 & \\
\hline & & Transport of loads & 3 & 10.0 & 2.5 & \\
\hline & & Transport of people & 7 & 23.3 & 6.0 & \\
\hline & & Leisure & 1 & 3.3 & 0.9 & \\
\hline \multirow[t]{3}{*}{$\begin{array}{l}\text { Dynamic formation and } \\
\text { commercialization }\end{array}$} & \multirow[t]{2}{*}{$\begin{array}{l}\text { Where the horses } \\
\text { originated }\end{array}$} & $\begin{array}{l}\text { State of Goiás, Central } \\
\text { Brazil }\end{array}$ & 2 & 28.6 & 1.7 & \\
\hline & & Southeast of Brazil & 2 & 28.6 & 1.7 & \\
\hline & \multicolumn{2}{|c|}{$\begin{array}{l}\text { Curraleiros were destined to the State of Mato Grosso, } \\
\text { West of Brazil }\end{array}$} & 3 & 42.8 & 2.5 & \\
\hline \multirow[t]{5}{*}{ Process of extinction } & \multicolumn{2}{|c|}{$\begin{array}{l}\text { Decrease of the Curraleiro effective population over the } \\
\text { years }\end{array}$} & 16 & 20.0 & 13.7 & \\
\hline & \multirow[t]{4}{*}{ Causes } & $\begin{array}{l}\text { Substitution of local horses } \\
\text { for official modern breeds }\end{array}$ & 36 & 45.0 & 30.8 & \\
\hline & & $\begin{array}{l}\text { Influence of external } \\
\text { trends }\end{array}$ & 7 & 8.7 & 6.0 & \\
\hline & & $\begin{array}{l}\text { Replacement by motor } \\
\text { vehicle }\end{array}$ & 18 & 22.5 & 15.4 & \\
\hline & & $\begin{array}{l}\text { Change in cattle } \\
\text { management }\end{array}$ & 3 & 3.8 & 2.5 & \\
\hline Total & & & 117 & & 100 & \\
\hline
\end{tabular}

$\mathrm{f}$ - Absolute frequency of ECUs; PS - Relative frequency to the primary subcategory; C3 - Relative frequency to category 3; TCat - Relative frequency to the total of ECUs including all five categories.

Regarding the primary subcategory Process of Extinction, respondents reported the number of Curraleiro horses has been decreasing over the years $(20.0 \%)$. Among the causes of this process of extinction, they highlighted the replacement of Curraleiros for other officially recognized horse breeds (45.0\%), mainly Mangalarga, Mangalarga Marchador, Campolina, and Quarter Horses. This subcategory was related to another one, denominated Influence by External Trends $(6.0 \%)$, in which respondents reported horse breeders from the State of Goiás preferred to raise well-known breeds instead of local horses. The exchange of local genetic animal material for modern or official varieties has been historically described as the main driver of extinction during the formation of local Brazilian horse breeds (Goulart, 1964; Santos et al., 1995; Braga, 2000). Replacement by motor vehicle was the second most cited cause surrounding the decrease in Curraleiro horse numbers $(22.5 \%)$. The introduction of automobiles, especially motorcycles, to replace the horses by the local farmers to carry out their daily chores, such as transportation of goods and cattle management, also has contributed to decrease the effective population of horses in Midwest and Central Brazil. Category 4 - Curraleiro horse conservation prospects (Table 4).

The appreciation and willingness, as well as the creation of animal conservation cores to preserve Curraleiro horses, stood out among respondents, each with a frequency of $31.0 \%$. In this context, breeders emphasized the importance of Curraleiro horses for local development of the northeast region in Goiás. Moreover, if the breed undergoes extinction, it will mean a great loss in terms of resources that may withstand local environmental challenges in regions of savanna. This has been extensively discussed in cases involving other Brazilian horse breeds used to manage livestock (Santos et al., 2003; Mcmanus et al., 2010a; Mcmanus et al., 2010b; Solano et al., 2013). The implementation of cores for Curraleiro horses, with respect to breeding and conservation, was discussed by the interviewees who suggested two suitable sites for core development: the village of Araí, also known as São Domingos, near Cavalcante, and regions containing native pastures located between Araí and Cavalcante, in Goiás. 
Table 4. Absolute and relative frequencies of the subcategories corresponding to Category 4 - Curraleiro horse conservation prospects - in a study regarding the speech content analysis in central Brazil

\begin{tabular}{|c|c|c|c|c|c|}
\hline \multicolumn{6}{|c|}{ Category 4: Curraleiro horse conservation prospects } \\
\hline Primary Subcategory & $\begin{array}{c}\text { Secondary } \\
\text { Subcategory }\end{array}$ & $\mathrm{f}$ & $\begin{array}{l}\text { PS } \\
(\%)\end{array}$ & $\begin{array}{l}\mathrm{C} 4 \\
(\%)\end{array}$ & $\begin{array}{l}\text { TCat } \\
(\%)\end{array}$ \\
\hline \multicolumn{2}{|c|}{ Awareness about the process of extinction } & 4 & - & 13.8 & \multirow{7}{*}{5.8} \\
\hline \multicolumn{2}{|c|}{ Appreciation and willingness of conservation } & 9 & - & 31.0 & \\
\hline \multicolumn{2}{|c|}{ Use of horses for sightseeing in the county of Cavalcante } & 5 & - & 17.2 & \\
\hline Difficulty to implement cor & tion projects & 2 & - & 6.9 & \\
\hline \multirow[t]{2}{*}{$\begin{array}{l}\text { Possible locations of future } \\
\text { conservation cores }\end{array}$} & $\begin{array}{l}\text { Native pastures between Araí village and the } \\
\text { county of Cavalcante }\end{array}$ & 7 & 77,8 & \multirow[t]{2}{*}{31.0} & \\
\hline & Araí village (São Domingos) & 2 & 22,2 & & \\
\hline \multicolumn{2}{|l|}{ Total } & 29 & 100 & 100 & \\
\hline
\end{tabular}

$\mathrm{f}$ - Absolute frequency of ECUs; PS - Relative frequency to the primary subcategory; C4 - Relative frequency to category 4; TCat - Relative frequency to the total of ECUs including all five categories.

In $17.2 \%$ of ECUs in category 4 , the usefulness of Curraleiro horses for sightseeing in the region of Cavalcante was discussed. This could be a key strategy to develop conservational projects for this kind of horse. Any project for a conservation core should also see the horses as a potential tool for fundraising for local breeders, which in turn will encourage them to value their stock. Moreover, eco adventures and green travel must also be stimulated in parallel, as an alternative scheme to subsidize conservation. ECUs regarding the awareness of respondents about the risk of extinction of Curraleiro horses indicated a reasonable collective consciousness among interviewees (13.8\%). Analyzing the UCEs it became clear that interviewees consistently stated that without conservation strategies, Curraleiro horses could become extinct in the nearby future. The bottlenecks in implementing conservation projects were the subject of $6.9 \%$ of ECUs in Category 4. The respondents reported they never thought about creating a breeder association of Curraleiro horse due to the lack of incentive for breeding and keeping this particular type of horse. Due to the low-income profile of horse owners in the area surveyed, keepers would not welcome expensive conservational projects. This observation reinforces the need to treat the horses as a source of income for their breeders in a conservation core.

Category 5 - Sanitary and productive aspects of Curraleiro horse breeding (Table 5).

Feeding native pastures to Curraleiro horses was highlighted in the category 5 (34.8\%). Respondents reported the grass known as "capim agreste" (Trachypogon spicatus), present in the Historical and Cultural Heritage Site Kalunga, was adequate to feed the local horses. The genuine Curraleiro Pé-Duro cattle breed from Brazil has been fed this type of fodder throughout decades (Moura et al., 2011).

Table 5. Absolute and relative frequencies of the subcategories corresponding to Category 5 - Sanitary and productive aspects in Curraleiro horse breeding - in a study regarding the speech content analysis in central Brazil

\begin{tabular}{l|c|c|c}
\hline Category 5: Sanitary and productive aspects of Curraleiro horse breeding & $\mathrm{f}$ & $\begin{array}{c}\text { C5 } \\
(\%)\end{array}$ & $\begin{array}{c}\text { TCat } \\
(\%)\end{array}$ \\
\hline Primary Subcategory & 8 & 34.8 & 4.6 \\
\hline Feeding with native pastures & 7 & 30.4 & \\
\hline Possible resistance to Equine Infectious Anemia & 4 & 17.4 \\
\hline Errors in the sanitary and feeding management of horses & 4 & 17.4 & \\
\hline Difficulty in identifying male horses that are not castrated & 23 & 100 & \\
\hline Total & & & \\
\hline
\end{tabular}

f - Absolute frequency of ECUs; C5 - Relative frequency to category 5; TCat - Relative frequency to the total of ECUs of the five categories. 
Some interviewees described Curraleiro horses as animals resilient to Equine Infectious Anemia (EIA) $(30.4 \%)$. According to their reports, several horses died with EIA in the past. Nowadays, decreased incidence of EIA has been observed in the region of Cavalcante. Based on speech analysis, it would be appealing to test in future researches whether Curraleiro horses raised in the northeastern region of Goiás (Brazil) show any resistance to EIA, as a result of natural selection. The Brazilian horse breeds Pantaneiro and Lavradeiro have also been reported as resistant to EIA (Santos et al., 2003; Mcmanus et al., 2010b).

Inadequate feeding, especially during the dry seasons when pastures present lower nutritional value, consequently leads to deterioration of health and body condition. This observation was a recurrent issue in the ECUs of category 5. Management failure has been the main cause of undernourishment of horses in Cavalcante, Nova Roma, and Iaciara. Again, the low-income profile of Curraleiro horse keepers limit the provision of food supplementation for livestock. Informants admitted specialized assistance is necessary and official encouragement to have an efficient horse-breeding program in sanitary and productive aspects.

Due to the temperament of stallions, castration of males is generally performed. According to horse keepers, castration is carried out when animals are around three to four years of age. If neutering is performed earlier, animals tend to remain restless. Due to the common habit of neutering Curraleiro horses, it has become constantly more difficult to find stallions available for reproduction.

\section{CONCLUSIONS}

Overall, we rediscovered a traditional horse ecotype cited in literature as being local to some regions of the Brazilian Savana during the early twentieth century accessing small rural communities. The Curraleiro horses seem to be more likely found in small rural communities of the northeast region of the State of Goiás, in accordance to historical literature. Although rare, this horse variety show common features which discriminate them from any equine breed officially recognized in Brazil. Historic aspects of Curraleiro horses has been reconstructed by a combination of oral narrative, suggesting the existence of sturdy animals that overcame rough conditions and became a genetic resource for the life of family farmers. Speech content analysis was effective to identify the Curraleiro, as well as characterize phenotypical aspects. We also highlight that this horse should be subject to conservation efforts and research regarding genetic diversity. The results of this study open the door for subsequent research i.e. population genetics and molecular biology. In addition, speech content analysis seems to be a valuable tool to be used in favor of conservation genetics worldwide.

\section{REFERENCES}

AMARAL, L.A.; TORRES, A.; RABASSA, V. et al. Limiar anaeróbico (V4) e frequência cardíaca de cavalos Crioulos condicionados para prova funcional. Arq. Bras. Med. Vet. Zootec., v.65, p.181-188, 2013.

BARDIN, L. Análise de conteúdo. 3.ed. Lisboa: Edições, 2004. p.70.

BRAGA, R.M. (Ed.). Os cavalos trazidos para o Brasil. Cavalo Lavradeiro em Roraima: Aspectos históricos, ecologia e de Conservação. Brasília: Embrapa, 2000. 119p.

EGITO, A.A.; MARIANTE, A.S; ALBUQUERQUE, M.S.M. Programa brasileiro de conservação de recursos genéticos. Arch. Zootec., v.51, p.39-52, 2002.

GORDO, J.M.L.; SILVA, M.C.; SOLANO, G.A. et al. Cattle farmers: profile and speech content analysis while undergoing training to adopt artificial insemination in Goiás state, Brazil. Rev. Bras. Zootec., v.42, p.162-167, 2013.

GOULART, J.A. (Ed.). O cavalo na formação do Brasil. Rio de Janeiro: Letras e Artes, 1964. $249 \mathrm{p}$.

HERMSDORFF, G.E. (Ed.). Zootecnia especial. Rio de Janeiro: Imprensa Nacional, 1956. 625 p.

LLOYD, R.; FELDWICK, W.; DELANEY, L.T. Impressões do Brazil no século vinte. Sua história, seo povo, commercio, industrias e recursos. London: Lloyd's Greater Britain Publishing Company Ltd, 1913. 
MARKS, D. Conformation and Soundness. In: of the ANNUAL CONVENTION OF THE AMERICAN ASSOCIATION OF EQUINE PRACTITIONERS, 46, 2000, San Antonio, Texas. Proceedings... San Antonio, Texas: editora, 2000. p.39-45. (Resumo).

MARQUES, J.R.F.; COSTA, M.R; SILVA, A.O.A. et al. Banco de recursos genéticos animais. Biotecnol. Ciênc. Desenvol., n.21, p.3239, 2001.

MCMANUS, C.; GOULART, H.M.; SEIXAS, L. et al. Cavalo Lavradeiro. Brasília: INCT, 2010b. (Série Técnica: Genética). Disponível em:

<http://animal.unb.br/images/Serie_tecnica_cava lo_lavradeiro.pdf.> . Acessado em: 23 ago. 2017.

MCMANUS, C., MARQUES, J.R.F., PAIVA, S. et al. Cavalos Marajoara e Puruca. Brasília: INCT, 2010a. (Série Técnica: Genética)., 2010a. Disponível em: <http://www.animal.unb.br/images/Serie_tecnica _cavalo_marajoara_puruca.pdf $>$. Acessado em: 23 ago. 2017.

MELO, J.B.; PIRES, D.A.F.; RIBEIRO, M.N. et al. Estudo zoométrico de remanescentes da raça equina Nordestina no município de Floresta. Actas Iberoam. Conserv. Anim., n.1, p.71-74, 2011.

MOURA, M.L.; TORRES, T.F.; MONTEIRO, E.P. Evolução de um rebanho de bovinos Curraleiro reintroduzido em cerrado nativo na região nordeste do estado de Goiás, Brasil. Actas Iberoam. Conserv. Anim., n.1, p.123-126, 2011.

NEUENDORF, K.A. The content analysis guidebook. 2.ed. Los Angeles: Sage, 2017. 403p.

PRODUÇÃO da pecuária municipal. Rio de Janeiro: IBGE, 2013. v.41

SANTOS, A.S.; MAZZA, M.C.M.; SERENO, J.R.B. et al. Avaliação e conservação do cavalo Pantaneiro. Corumbá: Embrapa Pantanal. 1995. (Circular técnica, n.21).
SANTOS, S.A.; MCMANUS, C.; MARIANTE, A.S. et al. Estratégias de conservação in situ do cavalo pantaneiro. Corumbá: Embrapa, 2003. p.1-29. (Documentos, n 55).

SILVA, A.C.M.; PAIVA, S.R.; ALBUQUERQUE, M.S.M. et al. Genetic variability in local Brazilian horse lines using microsatellite markers. Genet. Mol. Res., v.11, p.881-890, 2012.

SILVA, H.J. (Ed.). O Brasil. Suas riquezas naturaes. Suas industrias: Industria pastoril. Rio de Janeiro: Centro de serviços gráficos do IBGE, 1908.

SILVA, M.C.; FIORAVANTI, M.C.S.; SOLANO, G.A. et al. Análise do discurso em reunião para o registro genealógico de bovinos curraleiro pé-duro no brasil. Actas Iberoam. Conserv. Anim., n.3, p.188-193, 2013.

SOLANO, G.A.; SILVA, M.C.; ROCHA, F.E.C. et al. Análise do discurso de criadores de cavalo Campeiro no Sul do Brasil: instrumento de diagnóstico para conservação e fortalecimento da raça. Actas Iberoam. Conserv. Anim., n.3, p.8-14, 2013.

THE STATE of the world's animal genetic resources for food and agriculture - in brief, edited by Dafydd Pilling and Barbara Rischkowsky. Rome: FAO, 2007. 39p.

TORRES, A.P.; JARDIM, W.R. Criação do cavalo e de outros equinos. São Paulo: Nobel, 1979. 654p.

WEIBLEN, C.; MACHADO, G.; JESUS, F.P.K.D. et al. Seroprevalence of Pythium insidiosum infection in equine in Rio Grande do Sul, Brazil. Ciênc. Rural, n.46, p.126-131, 2015. 